\title{
Transfer and Expression of Cucumber Mosaic Virus Coat Protein Gene in the Genome of Cucumis sativus
}

\author{
Paula P. Chee and Jerry L. Slightom \\ Molecular Biology Division, The Upjohn Company, 301 Henrietta Street, Kalamazoo, MI 49007 \\ Additional index words. Agrobacterium, cucumber, regeneration, tissue culture, T-DNA, transformation
}

\begin{abstract}
Cotyledon explants of cucumber (Cucumis sativus L. CV. Poinsett 76) seedlings were cocultivated with disarmed Agrobacterium strain C58Z707 that contained the binary vector plasmid pGA482GG/cpCMV19. The T-DNA region of this binary vector contains plant-expressible genes for neomycin phosphotransferase II (NPT II), $\beta$-glucuronidase (GUS), and the coat protein of cucumber mosaic virus strain $\mathrm{C}$ (CMV-C). After infection, the cotyledons were placed on Murashige and Skoog medium containing $100 \mathrm{mg}$ kanamycidliter. Putative transformed embryogenic calli were obtained, followed by the development of mature embryos and their germination to plants. All transformed $\mathbf{R}_{0}$ cucumber plants appeared morphologically normal and tested positive for NPT IL Southern blot analysis of selected cucumber DNAs indicated that NPT II, GUS, and CMV-C coat protein genes were integrated into the genomes. Enzyme-linked immunosorbent assay and Western blot analysis indicated that the CMV-C coat protein is present in the protein extracts of progeny plants. These results show that the Agrobacterium-mediated gene transfer system and regeneration via somatic embryogenesis is an effective method for producing transgenic plants in Cucurbitaceae.
\end{abstract}

Many species of the Cucurbitaceae are susceptible to infection by Agrobacterium pathogens (Anderson and Moore, 1979; Smarrelli et al., 1986; Trulson et al., 1986). In addition, procedures for regenerating several of these species have already been established (Chee, 1990a, 1991a, 1991b). The combination of these two facts suggests that the transfer of genetic information into the genome of cucurbit species via an Agrobacterium -mediated transfer system should be feasible (Chee, 1990b). Such a transfer system would be useful for engineered genes that confer protection from viral infection (Cuozzo et al., 1988; Powell-Abel et al., 1986) and herbicides (Comai et al., 1985; dells-Cioppa et al., 1987; Lee et al, 1988; Stalker et al., 1985). Most of these genetic traits are difficult to acquire via conventional plant breeding, even virus protection (Providenti, 1985).

The sequence of the coat protein gene from CMV-C has been reported (Quemada et al., 1989) and has recently been engineered for expression in plants (Quemada et al., 1991). The development of cucumber plants that use the coat-protein-mediated mechanism for CMV protection (Powell-Abel et al., 1986) would be of scientific interest because this would allow for sideby-side comparisons of these genetically engineered plants with those plants that possess naturally occurring resistance. Coatprotein-mediated protection from CMV infections has been demonstrated in tobacco (Cuozzo et al., 1988; Quemada et al., 1991).

The present report describes the use of a disarmed strain of Agrobacterium tumefaciens to mediate the transfer of the engineered CMV-C coat protein into cucumber. In addition, it describes the use of regeneration via somatic embryogenesis to obtain morphologically normal and fertile transformed plants that express the CMV-C coat protein gene.

\footnotetext{
Received for publication 15 Oct. 1990. We thank Krystal A. Fober for plant care in the greenhouse; G. An, Washington State Univ., for his gift of the binary plasmid pGA482; A. Hepburn, Univ. of Illinois-Urbana, for his gift of the disarmed Agrobacterium strain CS8Z707; and D. Gonsalves, Cornell Univ., for the anti-CMV-C antibody. The cost of publishing this paper was defrayed in part by the payment of page charges. Under postal regulations, this paper therefore must be hereby marked advertisement solely to indicate this fact.
}

\section{Materials and Methods}

$T$-DNA vector. The T-DNA region of the Agrobacterium Ti plasmid-derived binary plasmid pGA482 (An, 1986) contains a kanamycin-resistance-selectable marker gene, NPT II, driven by the nopaline synthase (NOS) promoter. The T-DNA region also contains a multiple-cloning site, the cauliflower mosaic virus (CaMV) 35S promoter-driven GUS gene (Jefferson et al., 1987), and the coat protein gene from CMV-C (Quemada et al., 1991). To facilitate the transfer of this binary vector into various Agrobacterium strains, a bacterial gentamicin gene (Allmansberger et al., 1985) was cloned outside of the T-DNA region to obtain the plasmid referred to as pGA482GG/cpCMV19 (Fig. 1).

Plant material. Seeds of 'Poinsett 76' cucumber (Asgrow Seed Co., Kalamazoo, Mich.) were soaked in tap water for $\approx 15$ min. The seedcoats were removed manually. The decoated seeds were surface-sterilized with $70 \%$ alcohol for $1 \mathrm{~min}$. A 25 -min treatment with a $25 \%(\mathrm{v} / \mathrm{v})$ solution of commercial bleach $(5.25 \%$ sodium hypochlorite) followed. The seeds were rinsed four times with sterile distilled water and germinated in darkness at $28 \mathrm{C}$ on $0.8 \%$ water agar (Difco Laboratories, Detroit) for 3 to 5 days. Unless otherwise stated, all media were supplemented with 3\% sucrose and solidified with $0.8 \%$ Phytagar (Gibco, Gaithersburg, Md.). The $\mathrm{pH}$ of all media was adjusted to 5.8 before autoclaving at $121 \mathrm{C}$ for $20 \mathrm{~min}$.

Transformation. Transformation of cucumber was performed according to Chee (1990b). Three- to 5-day-old in vitro-grown seedlings were used as donors of cotyledons, which were cut into 5-mm explants. The explants were submerged overnight in a diluted culture $\left(2 \times 10^{8}\right.$ cells $\left./ \mathrm{ml}\right)$ of the strain C58Z707/ pGA482GG/cpCMV19 (Hepburn et al., 1985; Quemada et al., 1991) (Fig. 1). This strain was grown in LB medium containing $25 \mathrm{mg}$ kanarnycin $(\mathrm{Km}) /$ liter. After gentle shaking to ensure that all edges were infected, the explants were blotted dry and cultured abaxial side down in a sterile $100 \times 20$-mm petri dish (20 pieces/dish) containing Murashige and Skoog (MS) medium

\footnotetext{
Abbreviations: $\mathrm{Cb}$, carbenicillin; CMV, cucumber mosaic virus; GUS, ( $\beta$-glucuronidase; Km, kanamycin; MS, Murashige and Skoog NPT II, neomycin phosphotransferase II; NOS, nopaline synthase.
} 


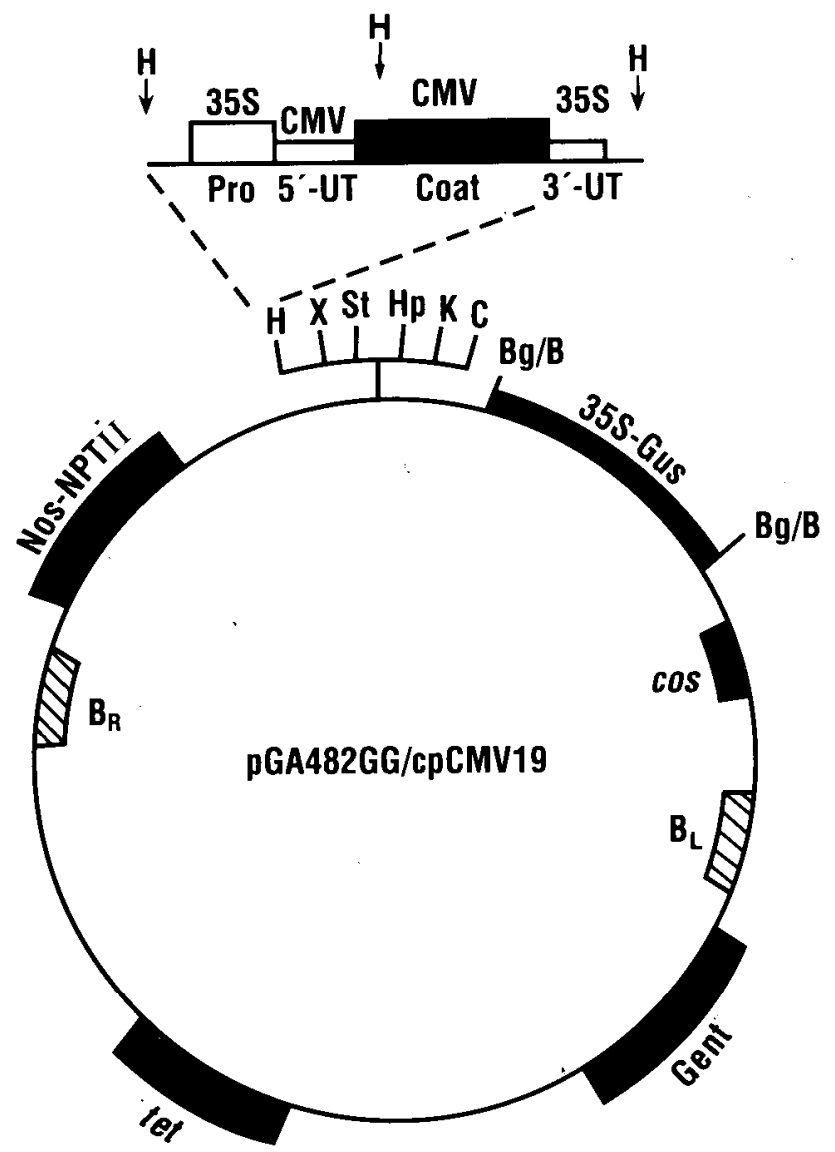

Fig. 1. Structure of the binary plasmid pGA482GG/cpCMV19. The plasmid is a derivative of pGA482 (An, 1986) that contains the TDNA border fragments of pTi37 (labeled $\mathrm{B}_{\mathrm{R}}$ and $\mathrm{B}_{\mathrm{L}}$, the cos site of bacterial phage $\lambda$, a restriction enzyme polylinker, and the NOSNPT II fusion gene. The bacterial gentamicin gene, labeled "Gent", was added to aid the transfer of the binary into Agrobacterium. The plant-expressible bacterial GUS gene was cloned into the BglII site of the polylinker. The CMV-C coat protein gene was engineered for expression and cloned into the HindIII site of the polylinker (Quemada et al., 1991). Restriction enzyme sites are: $\mathrm{Bg} / \mathrm{B}$, nondigestible fusion of BglII and BamHI sites; C, ClaI; H, HindIII; Hp, HpaI; K, KpnI; St, StuI; and X, XbaI.

+ $2.0 \mathrm{mg}$ 2,4-dichlorophenoxyacetic acid (2,4-D)/liter + 0.5 $\mathrm{mg}$ kinetin/liter (Chee, 1990a). After 4 days of growth in darkness at $26 \mathrm{C}$, the infected cucumber explants were transferred to petri plates containing MS medium $+500 \mathrm{mg}$ carbenicillin $(\mathrm{Cb}) / \mathrm{liter}+100 \mathrm{mg} \mathrm{Km} / \mathrm{liter}$ and cultured as before for $5 \mathrm{ad}-$ ditional weeks at $26 \mathrm{C}$ in darkness.

Plant regeneration. Putative transformed embryogenic calli were regenerated according to Chee (1990a). After 5 to 6 weeks on initiation medium, the emerging cotyledon callus pieces were transformed to MS medium + $1.0 \mathrm{mg} \mathrm{NAA}+0.5 \mathrm{mg}$ kinetin $+100 \mathrm{mg} \mathrm{Km}+500 \mathrm{mg} \mathrm{Cb}$, all per liter, for somatic embryo development. The environment for this stage was 2 weeks at $26 \mathrm{C}$ with a 16-h photoperiod under diffuse cool-white fluorescent lamps $\left(80 \mu \mathrm{mol} \cdot \mathrm{m}^{-2} \cdot \mathrm{s}^{-1}\right)$. The tissues were then transferred to hormone-free MS medium $+50 \mathrm{mg} \mathrm{Km} /$ liter for germination to plantlets under the same environment. When plantlets had developed an extensive root system on the latter medium, they were transplanted to 0.5 -liter pots containing ProMix (peat-lite/soilless mix; Florist Products, Schaumburg, 111.) and covered with plastic storage bags for acclimation. Subse- quently, the regenerated plants were potted in 8-liter pots containing soil mixture (Metro Mix 300R; Florist Products) and grown in a greenhouse.

NPT II enzyme assay. NPT II enzyme activity was detected by the in situ gel assay procedure (Chee et al., 1989; Reiss et al., 1984). About $100 \mathrm{mg}$ of cucumber callus or regenerated fresh leaf tissue was mixed with $20 \mu$ of extraction buffer in a 1.5-ml Eppendorf tube. The tissue was macerated with a Konte pestle and centrifuged at $10,000 \times \mathrm{g}$ for $15 \mathrm{~min}$ at $4 \mathrm{C}$ to remove cell debris. From each sample tested, a 35- $\mu$ l aliquot of the supernatant solution was electrophoresed on a $10 \%$ nondenaturing polyacrylamide gel, which was then exposed to Km sulfate and $\left.{ }^{32} \mathrm{P}-\gamma\right]$-ATP. Phosphorylated Km produced in those regions of the gel containing the modified bacterial NOS-NPT II enzyme activity was blotted onto phosphocellulose paper and detected by autoradiography.

Qualitative fluorometric GUS assay. GUS expression was determined by the qualitative fluorometric procedure of Jefferson et al. (1987). About $50 \mathrm{mg}$ of tissue was mixed with 200$\mu \mathrm{l}$ of lysis buffer (50 $\mathrm{mm} \mathrm{NaPO}_{4}, \mathrm{pH} 7.0,10$ mm EDTA, 0.1\% sarkosyl, $10 \mathrm{~mm} \beta$-mercaptoethanol) containing $1 \mathrm{~mm} 4$-methyl umbelliferyl glucuronide. The tissue was macerated and centrifuged for $15 \mathrm{~min}$ at $4 \mathrm{C}$. Fifty microliters of each supernatant sample was transferred to a 96-well plate and incubated overnight at 37C. The reactions were stopped with $125 \mu \mathrm{l}$ of 0.25 $\mathrm{M} \mathrm{Na}_{2} \mathrm{CO}_{3}$. The blue fluorescence was observed visually with a long-wavelength ultraviolet (UV) light box.

Genomic DNA isolation. Total nucleic acids were extracted from cucumber leaves using the cetyltrimethylammonium bromide procedure described by Saghai-Maroof et al. (1984). These extracted DNAs were not subjected to any further purification steps as they were readily digested by the restriction enzymes.

Genomic blot hybridization. Genomic DNA from individual cucumber plants (between 5 to $10 \mu \mathrm{g}$ ) was digested with a 5fold excess of either BamHI and HindIII or only HindIII enzymes, then electrophoresed in a $0.7 \%$ agarose gel. The gel was then electroblotted onto nylon fiber (Reed and Mann, 1985). Blotted filters were fixed by exposure for $3 \mathrm{~min}$ to a UV light source, then prehybridized in Denhardt (1966) solution [6x hybridization solution contains $0.9 \mathrm{M} \mathrm{NaCl} ; 0.09 \mathrm{M} \mathrm{Na}$ citrate, pH 7.2; and 0.02\% bovine serum albumin, PVP-40 (Sigma, St. Louis), and Ficoll-400 (Sigma)] for at least $2 \mathrm{~h}$ at 68C. Filters were hybridized against either a nick-translated 32P-labeled (Maniatis et al., 1982) 600 bp BglII-NcoI fragment containing mostly NPT II coding sequences (Beck et al., 1982), a ${ }^{32} \mathrm{P}-$ labeled $600 \mathrm{bp} \mathrm{BamHI}$ fragment from pUC1813 that contained the GUS coding sequences (Jefferson et al, 1987), or a ${ }^{32} \mathrm{P}$ labeled $1700 \mathrm{bp}$ EcoRI fragment from phage $\lambda$ clone CMV 9.9 that contained the CMV-C coat protein gene (Quemada et al., 1989). DNA labeling was done using a commercial kit (Bethesda Research Laboratories, Bethesda, Md.). Hybridizations were done using $7.5 \times 10^{5}$ counts per minute $(\mathrm{cpm})$ of the labeled probe per milliliter of hybridization buffer containing $2 \%$ sodium dodecyl sulfate (SDS), and incubating at $68 \mathrm{C}$ for at least $18 \mathrm{~h}$. Hybridized filters were washed in $1 \times$ hybridization solution (Denhardt, 1966) for $1 \mathrm{~h}$ at $68 \mathrm{C}$, dried, and then exposed to film for 12 to $24 \mathrm{~h}$.

Protein extract preparation and coat protein detection. Proteins were extracted from lyophilized leaf materials by handgrinding $100 \mathrm{mg}$ of sample in $1.0 \mathrm{ml}$ of sample extraction buffer [750 mM Tris. HCl, $\mathrm{pH} 8.8 ; 4 \%$ SDS (w/v); 4\% (3-mercaptoethanol (w/v); and $40 \%$ sucrose (w/v)]. After heating for $10 \mathrm{~min}$ at $100 \mathrm{C}$, cell debris was separated by centrifugation at $10,000 \times$ 
$\mathrm{g}$ for $10 \mathrm{~min}$. Protein was quantified by the Bradford assay (Bradford, 1976). Protein extracts were fractionated on $12 \%$ SDA-PAGE (Lammeli, 1970) and then transferred onto polyvinylidene difluoride membranes (Immobilon, Millipore, Bedford, Mass.) by electroelution (Towbin et al., 1979). Membranes were blocked at $25 \mathrm{C}$ for $1 \mathrm{~h}$ in Tris buffered saline (TBS) (20 mu Tris, $500 \mathrm{~mm} \mathrm{NaCl}, \mathrm{pH} 7.5$ ) that contained $2 \%$ nonfat milk, then were incubated overnight at $4 \mathrm{C}$ in TBS containing $3 \mu \mathrm{g}$ of anti-CMV IgG/ml, followed by protein A gold conjugate solution (Bio-Rad) for 2 to $4 \mathrm{~h}$. The color intensity of stained bands was enhanced by incubating the membrane in $100 \mathrm{ml}$ of enhancement 'solution $(90 \mathrm{ml}$ of citrate buffer containing $0.85 \mathrm{~g}$ hydroquinone $+10 \mathrm{ml}$ of silver lactate solution at $11 \mathrm{mg} \cdot \mathrm{ml}^{-1}$ ). Enzyme-linked immunosorbent assay (ELISA) was performed by the double-antibody sandwich technique, and $200 \mu \mathrm{l}$ of antigen was quantified using the alkaline phosphatase assay (Clark and Adams, 1977).

\section{Results and Discussion}

Regeneration of transformed cucumber plantlets. After 6 weeks on initiation medium, a characteristic gel-like callus tissue former! on the surface of the infected explants, particularly at the site where tissue contacted. the culture medium. The upper part of this tissue contained small sectors of putative embryogenic tissue (Chee, 1990a). These were selected for transfe to the secondary medium supplemented with $100 \mathrm{mg} \mathrm{Km} / \mathrm{liter}$ After transfer, such structures developed into embryos With normal morphology and subsequently germinated into plantlets on MS medium without hormones but supplemented with $50 \mathrm{mg}$ $\mathrm{Km} / \mathrm{liter}$. More than 100 transgenic plants were obtained from eight separate infection experiments and all flowered and set seeds normally.

Detection of NPT II and GUS enzyme activities. More than $100 \mathrm{R}_{\mathrm{o}}$ plants passed the selective test for $\mathrm{Km}$ resistance. They were identifiable by their ability to form roots on MS medium $+50 \mathrm{mg} \mathrm{Km} / \mathrm{liter}$. In contrast, nontransgenic control plants were inhibited from root development on this medium. To determine their transformation status after plant regeneration, each plant was tested for the presence of NPT II enzyme activity. Figure 2 shows an example of this analysis for NPT II enzyme activity in the protein extracts of 16 transformed $R_{0}$ plants. Individual protein extracts from these putative transgenic $\mathrm{R}$ plants all showed some level of NPT II enzyme activity. This NPT II enzyme activity always comigrated with the activity associated with the control bacterial-derived NPT II enzyme. Variation in the level of this activity could be due to differences in the amount of protein extracted or to positional effects of having the nopaline synthase (NOS) promoter inserted at dif- ferent chromosomal locations in each plant (An et al., 1986) In contrast, noninfected control plants that resulted from cocultivation with C58Z707 minus the binary plasmid showed no comigrating NPT II activity in leaf extracts. Each plant was also tested for GUS activity. Only 10 NPT II-positive plants did not have GUS activity. These results suggest that not all transformed plants contained the complete T-DNA region, a result that is consistent with the directional transfer (right to left border) (Wang et al., 1984) of the T-DNA region of the vector pGA482GG/cpCMV19 (Fig. 1).

Southern blot analysis of transgenic $R$ cucumber plants. Total cucumber DNAs were isolated from 80 NPT II- and GUSpositive plants. These DNAs were first subjected to digestions with both BamHl and HindIII enzymes and all yielded the predicted $2.0 \mathrm{~kb}$ NOS-NPT II (An, 1986) hybridizing fragment (data not shown). The Southern blot result for four $\mathrm{R}_{0}$ plants are shown in Fig. 3. To determine whether the NOS-NPT II gene is indeed integrated within these genomic DNAs, these four DNAs were subjected to restriction endonuclease digestion with only HindIII (Fig. 3). Integration of the NOS-NPT II can be characterized for each transformation event because this gene is only flanked on its right side by a HindIII site (Fig. 1). Thus, the size of the hybridizing fragments is indicative of the location of the nearest HindIII site derived from the plant genome that flanks the opposite side of the NOS-NPT II gene. The presence of the four different size bands for this digestion indicated that each plant was derived from an independent transformation event (Fig. 3). In most cases, the HindIII digest yielded a single band, as seen for $R_{0}$ plant 1,36 , and 106 (Fig. 3), which suggests that a single T-DNA region has been integrated. However, plant 54 showed the presence of multiple bands (Fig. 3), which suggests that this genome may contain multiple T-DNA insertions.

Southern blot analyses of transgenic $R$, cucumber plants. Analysis of $85 \mathrm{R}_{1}$ plants derived from\& plant 36 showed that 75\% expressed NPT II activities (data not shown). Plant 36 was selected for further analyses because it appeared to contain a

1

34

$\begin{array}{llll}5 & 6 & 7 & 8\end{array}$

$9 \quad 10$ 
single T-DNA integration (see Fig. 3). Southern blot analysis of six $R_{1}$ plants derived from self-pollination of plant 36 are shown in Figs. 4 and 5. The blotted filters show the expected hybridization bands-at $2.0 \mathrm{~kb}$ for the NPT II gene (An, 1986)

$\begin{array}{llllllllll}1 & 2 & 3 & 4 & 5 & 6 & 7 & 8\end{array}$

$5.0 \mathrm{~kb}-$

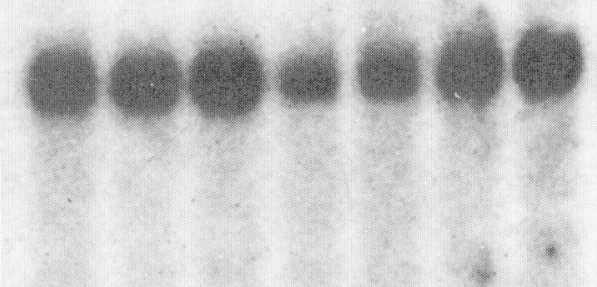

$2.0 \mathrm{~kb}$ -

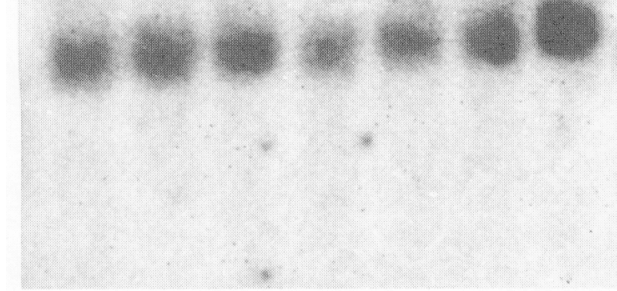

Fig. 4. Genomic blot analysis of NPT II and GUS genes for $R_{1}$ plant derived from $\mathrm{R}_{0}$ plant 36 . Lanes 1-6, DNAs isolated from 36-1, 2, $-3,-4,-5$, and -6 and digested with HindIII and BamHI; lane 8 , digest of DNA from a nontransformed cucumber plant; lane 7 , nontransformed cucumber plant DNA to which pGA482GG/cpCMV19 plasmid DNA had been added. Two hybridizing fragments, 2.0 and $5.0 \mathrm{~kb}$, correspond to expected NPT II- and GUS-gene-containing fragments, respectively. and $5.0 \mathrm{~kb}$ for the GUS gene (Jefferson et al., 1987) (Fig. 4). Hybridization of HindIII- and BamHI-digested transgenic cucumber DNAs with the 32P-labeled CMV-C coat protein gene fragment showed the expected $0.75-$ and $0.9-\mathrm{kb}$ hybridizing bands, while hybridization to this DNA digested with only HindIII showed the presence of a single band at $0.95 \mathrm{~kb}$ (Fig. 5). This $0.95-\mathrm{kb}$ band is a doublet because the CMV-C coat protein gene contains an internal HindIII site (Quemada et, al., 1989). This doublet can be separated by the BamHI digest because it removes » $200 \mathrm{bp}$ from the 3 ' end of the engineered CMV-C expression cassette (unpublished data).

Detection of coat protein polypeptides in $R_{1}$ plants. The results for immunological hybridization of protein extracts of 11 $\mathrm{R}_{1}$ plants derived from $\mathrm{R}_{0}$ plant 36 are shown in Fig. 6 . The coat protein polypeptides, measuring » $24 \mathrm{kDal}$, were found in these $11 \mathrm{R}_{1}$ plants. This polypeptide size is similar to that found for purified CMV-C coat protein (Fig. 6) and derived from the sequence of the CMV-C coat protein gene (Quemada et al., 1989). The level of coat protein present in $50 \mathrm{R}_{1}$ plants derived. from R0 plant 36, as determined by ELISA, is $14 \pm 6 \mathrm{ng} \cdot \mathrm{mg}^{-1}$ protein (Table 1), which is similar to the level of coat protein produced in transgenic tobacco plants (Quemada et al., 1991).

These experiments clearly showed that the Agrobacterium binary vector pGA482GG/cpCMV19, cloned within the disarmed Agrobacterium strain C58Z707, effectively transferred and integrated the CMV coat protein gene into the cucumber genome. The cucumber plant tissues used were from the CMVsusceptible cultivar Poinsett 76. This report also demonstrates that the CMV-C expression cassette is functional not only in tobacco (Quemada et al., 1991), but also in cucumber and is capable of producing about the same amount of CMV-C coat protein as in tobacco. The development of a series of transgenic cucumber plant lines containing and expressing the CMV-C coat protein gene provides plant material to determine whether this level of coat protein will be sufficient to protect cucumber plants from CMV. If so, these plants will be useful in determining the level of $\mathrm{CMV}$ resistance between transgenic plants containing

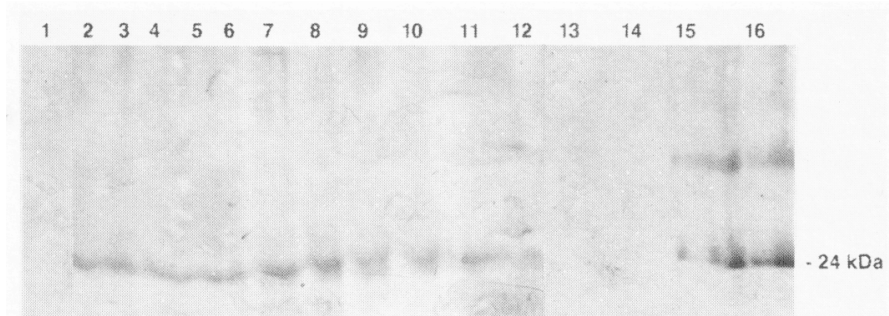

Fig. 6. Immunological detection of $\mathrm{CMV}-\mathrm{C}$ coat protein in $\mathrm{R}_{1}$ plants derived from $\mathrm{R}_{0}$ plant 36 . Lanes $2-12$, protein extracts of transformed $\mathrm{R}_{1}$ plants $36-1,-2,-3,-4,-5,-6,-7,-8,-9,-10$, and -11 ; lanes 13 and 14, extracts of two nontransformed plants; lanes 15 
the coat protein gene and natural resistance. Our preliminary field test results from infecting several of these transgenic plants with CMV suggest that CMV coat-protein gene expression does offer protection from CMV infections (Slightom et al., 1990).

\section{Literature Cited}

Allmansberger, R., B. Brau, and W. Piepersberg. 1985. Genes for gentamicin-(3)-N-acetyl-transferases III and IV: II nucleotide sequences of three $\mathrm{AAC}(3)-111$ genes and evolutionary aspects. Mol. Gen. Genet. 198:514-520.

An, G. 1986. Development of plant promoter expression vectors and their use for analysis of differential activity of nopaline synthase promoter in transformed tobacco cell. Plant Physiol. 81:86-91.

An; G., P.R. Ebert, B.-Y. Yi, and C.-H. Choi. 1986. Both TATA box and upstream regions are required for the nopaline synthase promoter activity in transformed tobacco cells. Mol. Gen. Genet. 203:245-250

Anderson, A.R. and L.W. Moore. 1979. Host specificity in the genus Agrobacterium. Phytopathology 69:320-323.

Beck, E., G. Ludwig, E.A. Auerswald, B. Reiss, and H. Schaller. 1982. Nucleotide sequence and exact localization of the neomycin phosphotransferase gene from transposon Tn5. Gene 19:327-336.

Bradford, M.M. 1976. A rapid and sensitive method for the quantitation of microgram quantities of protein utilizing the principle of protein-dye binding. Anal. Biochem. 72:248-254.

Chee, P.P. 1990a. High frequency of somatic embryogenesis and recovery of fertile cucumber plants. HortScience 25:792-793.

Chee, P.P. 1990b. Transformation of Cucumis sativus tissue by Agrobacterium tumefaciens and the regeneration of transformed plants. Plant Cell Rpt. 9:245-248.

Chee, P.P. 1991a. Somatic embryogenesis and plant regeneration of squash Cucurbita pepo L. cv. YC60. Plant Cell Rpt. 9:620-622.

Chee, P.P. 1991b. Plant regeneration from cotyledons of Cucumis melo 'Topmark'. HortScience 26:908-910.

Chee, P. P., K.A. Fober, and J.L. Slightom. 1989. Transformation of soybean (Glycine max) by infecting germinating seeds with Agrobacterium tumefaciens. Plant Physiol. 91:1212-1218.

Clark, M.F. and A.M. Adams. 1977. Characteristics of the microplate method of enzyme-linked immunosorbent assay for the detection of plant viruses. J. Gen. Virol. 34:475-483.

Comai, L., D. Facciotti, W.R. Hiatt, G. Thompson, R.E. Rose, and D.M. Stalker. 1985. Expression in plants of a mutant aroA gene from Salmonella typhimurium confers tolerance to glyphosate. Nature (London) 317:741-744.

Cuozzo, M., K.M. O'Connell, W. Kaniewski, R-X. Fang, N-H. Chua, and N. Turner. 1988. Viral protection in transgenic tobacco plants expressing the cucumber mosaic virus coat protein or its antisense RNA. Bio/Technology 6:549-557.

dells-Cioppa, G., C. Bauer, M.L. Taylor, D.E. Rochester, B.K. Klein, D.M. Shah, R.T. Fraley, and G. Kishore. 1987. Targeting a herbicide-resistant enzyme from $E$. coli to chloroplasts of higher plants. Biotechnology 5:579-584.

Denhardt, D.T. 1966. A membrane-filter technique for the detection of complementary DNA. Biochem. Biophysiol. Res. Commun. 23:641-646.

Hepburn, A. G., J. White, L. Pearson, M.J. Maunders, L.E. Clarke, A.G. Prescott, and K.S. Blundy. 1985. The use of pNJ5000 as an intermediate vector for genetic manipulation of Agrobacterium Tiplasmid. J. Gen. Microbiol. 131:2961-2969.
Jefferson, R.A., T.A. Kavanagh, and M.W. Bevan. 1987. GUS fusions: $\beta$-glucuronidase as a sensitive and versatile gene fusion marker in higher plants. EMBO J. 6:3901-3907.

Lammeli, U.K. 1970. Cleavage of structural proteins during the assembly of the head of bacteriophage T4. Nature (London) 227:680685.

Lee, K. Y., J. Townsend, J. Tepperman, M. Black, C.F. Chui, B. Mazur, P. Dunsmuir, and J. Bedbrook. 1988. The molecular basis of sulfonylurea herbicide resistance in tobacco. EMBO J. 7:12411248 .

Maniatis, T., E.G. Fritch, and J. Sambrook. 1982. Molecular cloning: A laboratory manual. Cold Spring Harbor Laboratory, Cold Spring Harbor, N.Y. p. 109-112.

Powell-Abel, P., R.S. Nelson, B. De, N. Hoffmann, S.G. Rogers, R.T. Fraley, and R.N. Beachy. 1986. Delay of disease development in transgenic plants that express the tobacco mosaic virus coat protein gene. Science 232:738-743.

Provvidenti, R,. 1985. Sources of resistance to viruses in two accessions of Cucumis sativus. Cucurbit Genet. Coop. 8:12.

Quemada, H.D., D. Gonsalves, and J.L. Slightom. 1991. Expression of coat protein gene from cucumber mosaic virus strain $\mathrm{C}$ in tobacco: Protection against infections by CMV strains transmitted mechanically or by aphids. Phytopathology 81:794-802.

Quemada, H., C. Kerney, D. Gonsalves, and J.L. Slightom. 1989. Nucleotide sequences of the coat protein genes and flanking regions of cucumber mosaic virus strains $\mathrm{C}$ and WL RNA 3. J. Gen. Virol. 70:1065-1073.

Reed, K.C. and D.A. Mann. 1985. Rapid transfer of DNA from agarose gels to nylon membrane. Nucleic Acids Res. 13:7207-7221.

Reiss, B., R. Sprengel, H. Will, and H. Schaller. 1984. A new sensitive method for qualitative and quantitative assay of neomycin phosphotransferase in crude cell extracts. Gene 30:211-218.

Saghai-Maroof, M.A., K.M. Soliman, R.A. Jorgensen, and R.W. Allard. 1984. Ribosomal DNA spacer-length polymorphisms in barley: Mendelian inheritance, chromosomal location, and population dynamics. Proc. Natl. Acad. Sci. USA 81:8014-8018.

Slightom, J. L., P.P. Chee, and D. Gonsalves. 1990. Field testing of cucumber plants which express the CMV coat protein gene: Field plot design to test natural infection pressures, p. 201-206. In: H.J.J. Nijkamp, L.H.W. van der Plass, and J. van Aartrijk (eds.). Progress in plant cellular and molecular biology. Academic Publishers, Dordrecht, The Netherlands.

Smarrelli, J., Jr., M.T. Watters, and L. Diba. 1986. Response of various cucurbits to infection by plasmid-harboring strains of Agrobacterium. Plant Physiol. 82:622-624.

Stalker, D. M., W.R. Hiatt, and L. Comai. 1985. A single amino acid substitution in the enzyme 5-enolpyruvylshikimate-3 -phosphate synthase confers resistance to the herbicide glyphosate. J. Biol. Chem. 260:4724-4728.

Towbin, H., T. Staehelin, and J. Gordon. 1979. Electrophoretic transfer of proteins from polyacrylamide gels to nitrocellulose sheets: Procedure and some applications, Proc. Natl. Acad. Sci. USA 76:4350-4354.

Trulson, A. J., R.B. Simpson, and E.A. Shahin. 1986. Transformation of cucumber (Cucumis sativus L.) plants with Agrobacterium rhizogenes. Theor. Applied Genet. 73: 11-15.

Wang, K., L. Herrera-Estrella, M. Van Montagu, and P. Zambryski. 1984. Right $25 \mathrm{bp}$ terminus sequence of the nopaline T-DNA is essential for and determines direction of DNA transfer from Agrobacterium to the plant genome. Cell 38:455-462. 